\title{
PECKING ORDER THEORY AND TRADE-OFF THEORY OF CAPITAL STRUCTURE: EVIDENCE FROM INDONESIAN STOCK EXCHANGE
}

\author{
Priska Ralna Eunike Culata; Tri Gunarsih \\ Universitas Teknologi Yogyakarta \\ Jl. Ringroad Utara, Jombor, Sleman, Yogyakarta \\ priska_08013@yahoo.com
}

\begin{abstract}
ABSRACT
Numerous empirical studies in the finance field have tested many theories for firms' capital structure. The pecking order theory and the trade-off theory of capital structure is among the most influential theories of firms' capital structure. The trade-off theory predicts optimal capital structure, while the pecking order theory does not predict an optimal capital structure. According to pecking order theory, the order of financial sources used is the source of internal funds from profits, short-term securities, debt, preferred stock and common stock last. The main objective of this study is to econometrically test whether the listed companies in Indonesian Stock Exchange follow the pecking order theory or the trade-off theory. Samples in this study are public companies listed during 2009-2010. The research questions are tested by running regression models. The empirical result of this study shows that the pecking order theory is not supported, while the trade-off theory is supported. This suggests that the capital structure of listed companies in Indonesian Stock Exchange is financed based on optimal capital structure, not by the order financial resources.
\end{abstract}

Keywords: capital structure, pecking order theory, trade-off theory

\begin{abstract}
ABSTRAK
Sejumlah studi empiris di bidang keuangan telah menguji banyak teori untuk struktur modal perusahaan. Teori pecking order dan teori trade-off dari struktur modal adalah salah satu teori yang paling berpengaruh dari struktur modal perusahaan. Teori trade-off memprediksi struktur modal yang optimal, sedangkan teori pecking order tidak. Menurut teori hierarki, urutan sumber keuangan yang digunakan adalah sumber dana internal dari keuntungan, sekuritas jangka pendek, utang, saham preferen dan sisa saham biasa. Tujuan utama dari penelitian ini adalah untuk menguji secara ekonometris apakah perusahaan yang terdaftar di Bursa Efek Indonesia mengikuti teori pecking order atau teori trade-off. Sampel dalam penelitian ini adalah perusahaan publik yang terdaftar selama tahun 2009-2010. Pertanyaan penelitian diuji dengan menjalankan model regresi. Hasil empiris dari studi ini menunjukkan bahwa teori pecking order tidak didukung, sedangkan teori trade-off didukung. Hal ini menunjukkan bahwa struktur modal perusahaan yang terdaftar di Bursa Efek Indonesia dibiayai berdasarkan pada struktur modal yang optimal, bukan oleh sumber daya tatanan keuangan.
\end{abstract}

Kata kunci: struktur modal, teori pecking order, teori trade-off 


\section{INTRODUCTION}

Numerous empirical studies in finance have tested many theories for firms' capital structure. The pecking order theory and the trade-off theory of capital structure is among the most influential theories of firms' capital structure. According to Myers (1984), firms finance their activities with retained earning when feasible. If the return earning are inadequate, then debt is used. Only in extreme cases will firms use new equity finance. Thus, the order of financial sources used was the source of internal funds from profits, short-term securities, debt, preferred stock and common stock last. Pecking order theory predicts that the issuance of equity (common stock) is the last alternative sources of funding. The trade-off theory, based on research on taxes (Modigliani and Miller, 1963) and bankruptcy and financial distress costs (Warner, 1977) and the insights from the agency literature (Jensen and Meckling, 1976), suggests that firms have a unique optimal capital structure that balances between the tax advantage of debt financing (i.e. debt tax shields), the costs of financial distress and the agency benefits and costs of debt (see Bradley et al., 1984; Leary and Roberts, 2005; Strebulaev, 2007). Then the trade-off theory predicts optimal capital structure, while the pecking order theory developed by Myers (1984) does not predict an optimal capital structure but the order of financial sources.

Most of the empirical studies of those theories had focused on U.S. firms and other developed country. While most existing studies focus on developed countries, it is interesting and important to assess the validity of the dominant theories of capital structure in Indonesia. Indonesian Stock Exchange is characterized, among other things, by the domination of large shareholders (Gunarsih, 2003), unlike another country that the main agency problems that occurred is between managers and company owners (shareholders). Thus the structure of corporate governance in Indonesia is different from other countries, such as the United States. Ownership structure of listed companies in Indonesia is concentrated on a few owners while the ownership structure in the United States is spreading to many owners with a relatively small proportion of ownership. In the concentrated ownership structure, the main agency problem is the majority holder with minority, while in the spread ownership, the main agency problem is between managers with the owner.

In this paper, we study the pecking order theory and trade-off theory of capital structure of publicly traded Indonesian companies with two reasons. First, the structure of corporate governance in Indonesia is different from other countries. Second, there are mixed results of empirical study in both theories. Some of them are supported but some others are not supported.

\section{Pecking Order Theory}

A large body of recent empirical research on capital structure focuses on testing the validity of the trade-off and pecking order theories, but the empirical results are not consistent yet. Some of empirical research are supported but some are not. Syam-Sunder and Myers (1999) find strong support for pecking order theory, while Frank and Goyal (2003) document weak evidence for the pecking order theory.

Pecking order theory (Myers and Majluf (1984) and Myers (1984)) and the extension of this theory (Lucas and McDonald, 1990) studied based on the asymmetric information between managers and investors. Managers have more information about the true value of the enterprise and enterprise risk compared to outside investors. According to Myers (1984), firms finance their activities with retained earning when feasible. If the return earning are inadequate, then debt is used. Only in extreme cases will firms use new equity finance. Thus, the order of financial sources used was the source of internal funds from profits, short-term securities, debt, preferred stock and common stock last. Pecking order theory predicts that the issuance of equity (common stock) is the last alternative sources of funding. 
As described by Myers (1984), the pecking order theory suggests that firms first prefer internal sources of finance, and they adjust their target dividend payout ratio to their investment opportunities. If the firms seek external finance, due to generous dividend policies, unpredictable fluctuations in profitability or investment opportunities, firms will choose debt (as the safest instrument), and then hybrid securities such as convertible bonds, and then equity as a last resort. The pecking order theory generally explains why firms might rationally let cash flows determine leverage. This suggests that firms turn to debt funds under pressure of an internal funds shortage.

Tsuji (2011) has surveyed the international evidence of the capital structure issues, particularly focusing on the pecking order theory of corporate financing. The result of the survey, both empirical and survey evidence are often different and contradictory. The mixed results of the survey are as in Table 1.

Table 1Survey Results of Pecking Order Theory

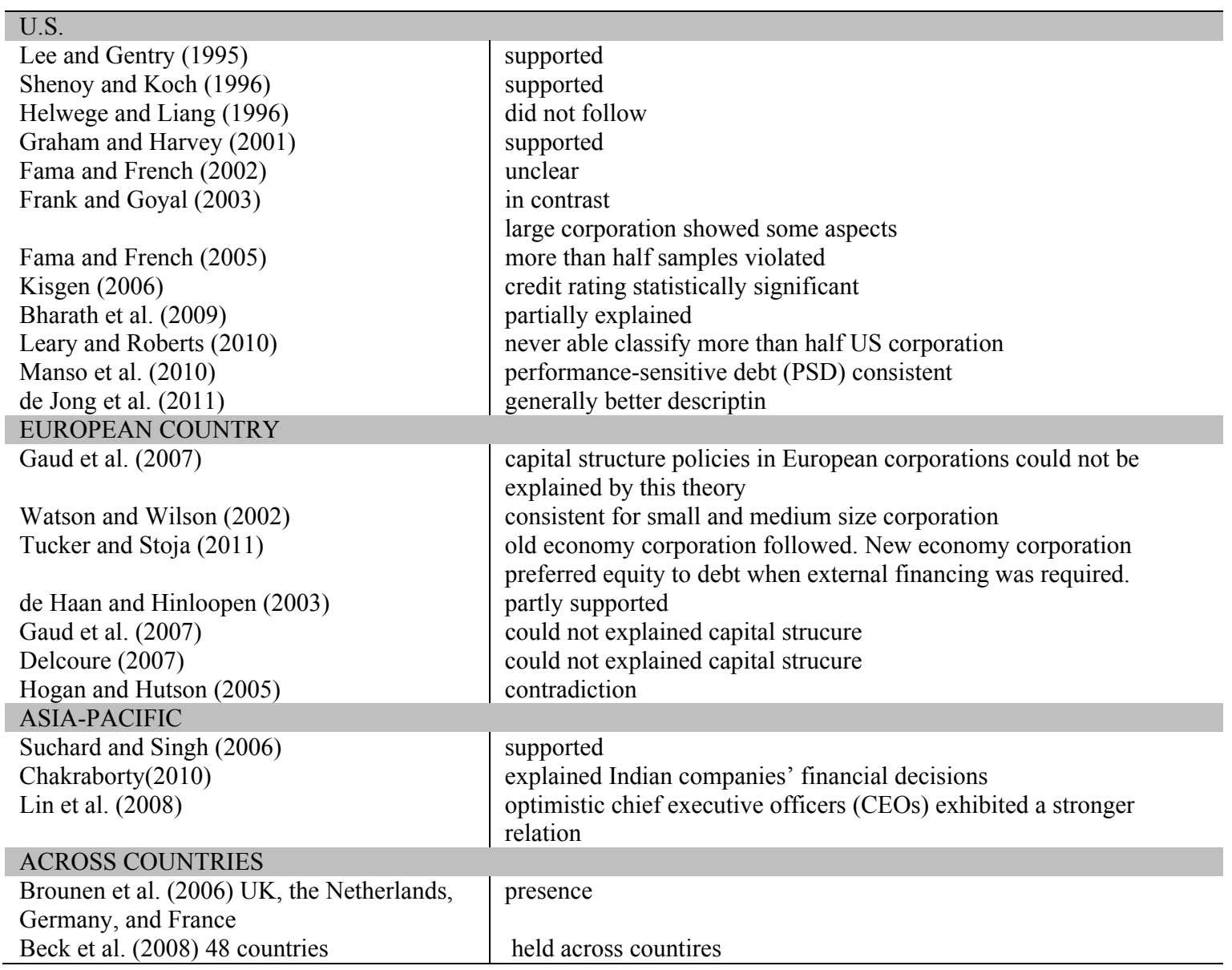

An important survey of Myers (2003, pp.235 in Tusji, 2011) documented the pecking order theory of corporate financing as following citations ((1) - (4)): (1) Firms prefer internal to external finance. (Information asymmetries are assumed relevant only for external financing); (2) Dividends are "sticky", so that dividend cuts are not used to finance capital expenditure, and changes in cash requirements are not soaked up in short-run dividend changes. Changes in free cash flow (operating cash flow less investment) show up as changes in external financing; (3) If external funds are required for capital investment, firms will issue the safest security first, that is, debt before equity. As the requirement for external financing increase, the firm will work down the pecking order, from safe to 
riskier debt and finally to equity as a last resort, when the firm is sufficiently threatened by financial distress. If internally, generated cash flow exceeds capital investment, the firm works up the pecking order. Excess cash is used to pay down debt rather than repurchasing and retiring equity; and (4) The firm's debt ratio therefore reflects its cumulative requirement for external financing.

\section{Trade-off Theory}

The trade-off theory, based on research on taxes (Modigliani and Miller, 1963) and bankruptcy and financial distress costs (Warner, 1977) and the insights from the agency literature (Jensen and Meckling, 1976), suggests that firms have a unique optimal capital structure that balances between the tax advantage of debt financing (i.e. debt tax shields), the costs of financial distress and the agency benefits and costs of debt. Then the trade-off theory predicts optimal capital structure.

Optimal capital structure is a combination of funding sources which consist of debt and stock that will yield the highest value of the firm. One indication of the high value of the company is the high stock prices. Thus, the optimal capital structure is a capital structure that generates the highest stock price. Another indication of an optimal capital structure is lowest cost of capital weighted (Weighted Average Cost of Capital - WACC). WACC is the combination cost of debt and capital stock that calculated by weighted average. According to Myers (1984), a firm that follows the tradeoff theory sets a target debt-to-value ratio and then gradually moves towards the target. The target is determined by balancing debt tax shields against costs of bankruptcy.

One of the capital structure theories is Modigliani and Miller (MM). MM explained that the companies that use debt will have higher firm value than firms that do not use debt. The higher the debt of the company (higher the ratio of debt to assets), the higher the value indicated by the value of company stock (Figure 1 on the line MM Result). But in reality, the continuous increase in debt will not increase firm value because it increases the risk of the company. The high debt will allow the risk of default (the default). If this happens then it will lower the value of the company. Actual conditions (Figure 1 actual line) are the firm value will increase with the increase in debt (leverage) companies. Increased leverage will increase the value companies until a certain level (Figure 1 second dotted line). Increased levels of leverage after the rule will reduce the value of the company as a result of the increased risk of corporate debt.

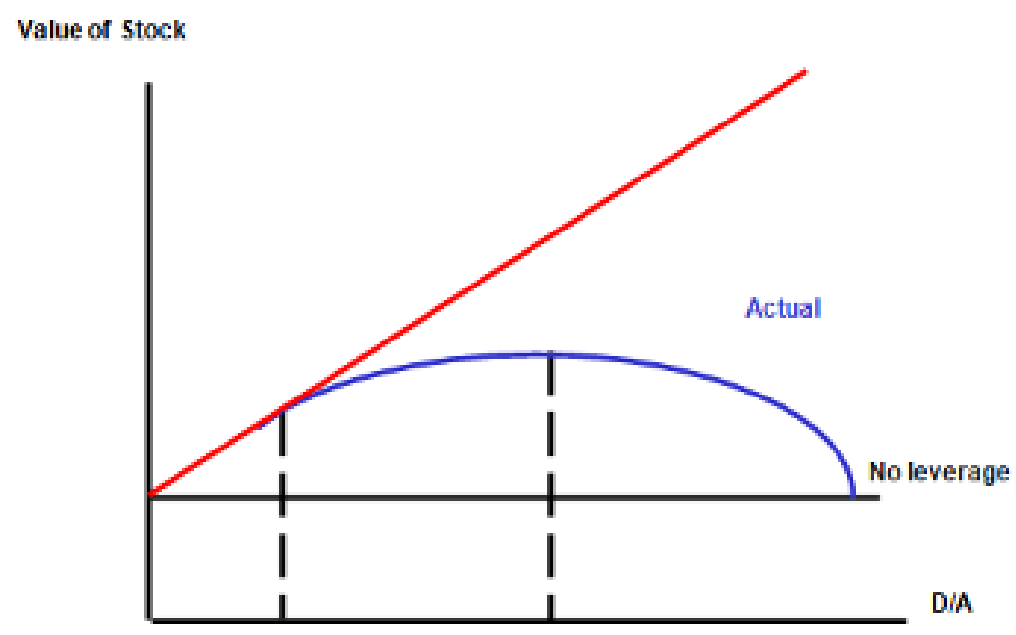

Figure 1. The value of shares and Leverage 
As in pecking order theories empirical research, the results of empirical research in trade-off theory are mixed. Fama and French (2002) concluded that the many shared predictions of the trade-off theory tended to do well in their tests, however, when shared predictions were confirmed, attributing theory was unclear. Frank and Goyal (2003) identified one inconsistency regarding the trade-off theory (i.e., the negative linkage between leverage and profitability). Tucker and Stoja (2011) suggested that the trade-off theory could explain certain aspects of UK companies' capital structure policies, neither supplied a satisfactory general explanation of their real-world behaviors.

\section{METHOD}

\section{Sample selection}

Samples in this study are public companies, listed in the Indonesian Stock Exchange years 2009-2010. The samples are selected using purposive sampling, base on the following criteria: (1) listed in the Indonesian Stock Exchange between 2009 - 2010; (2) the financial statement data are available for the reporting year 2009 - 2010; (3) the sample firms publish audited financial statements using reporting period ended on December 31.

\section{Model}

The pecking order theory tested using model as Shyam-Sunder and Myers (1999) and Cotei and Farhat (2008). Shyam-Sunder and Myers (1999) developed a model of the pecking order theory, where if the company needs funds from external parties, it will use debt rather than equity. Equity will only be used in very urgent, that is if the costs of financial distress due to be so high and the company's debt capacity has been exceeded. The first step is to solve equation (1). Equation (1) is used to test equation (2), (3), and (3). Each model with an explanation of the variables is described as follows.

$$
\Delta \mathrm{LTD}_{\mathrm{t}}+\Delta \mathrm{STD}_{\mathrm{t}}+\Delta \mathrm{EQ}_{\mathrm{t}}=\operatorname{Div}_{\mathrm{t}}+\mathrm{I}_{\mathrm{t}}+\Delta \mathrm{WC}_{\mathrm{t}}-\mathrm{C}_{\mathrm{t}}=\mathrm{Fin}_{\mathrm{t}}
$$

where:

$\Delta \quad$ : change of variables from time $t_{t-1}$ to $_{t}$

LTD $_{\mathrm{t}}$ : long-term debt time ${ }_{\mathrm{t}}$

STD $_{\mathrm{t}} \quad$ : short-term debt time ${ }_{\mathrm{t}}$

$\mathrm{EQ}_{\mathrm{t}} \quad$ : equities time ${ }_{\mathrm{t}}$

$\operatorname{Div}_{\mathrm{t}} \quad$ : cash dividend time ${ }_{\mathrm{t}}$

$\mathrm{I}_{\mathrm{t}} \quad$ : investment time ${ }_{\mathrm{t}}$

$\mathrm{WC}_{\mathrm{t}} \quad$ : working Capital time ${ }_{\mathrm{t}}$

$\mathrm{C}_{\mathrm{t}} \quad$ : cash time $\mathrm{t}_{\mathrm{t}}$

Fin $_{t} \quad:$ deficit / Surplus of Finance time ${ }_{t}$

$$
\Delta \mathrm{TD}_{\mathrm{t}}=\alpha_{0}+\alpha_{1} \mathrm{Fin}_{\mathrm{t}}+\phi_{\mathrm{t}}
$$

According to the Shyam-Sunder and Myers (1999) and Cotei and Farhat (2008) total financing debt is separated into long-term debt and short-term debt as follows.

$\mathrm{TD}_{\mathrm{t}}=\mathrm{LTD}_{\mathrm{t}}+\mathrm{STD}_{\mathrm{t}}$

$$
\begin{aligned}
& \Delta \mathrm{LTD}_{\mathrm{t}}=\delta_{0}+\delta_{1} \mathrm{Fin}_{\mathrm{t}}+\mathrm{v}_{\mathrm{t}} \\
& \Delta \mathrm{STD}_{\mathrm{t}}=\gamma_{0}+\gamma_{1} \operatorname{Fin}_{\mathrm{t}}+\xi_{\mathrm{t}}
\end{aligned}
$$


1.

The simplest form of the pecking order model is the prediction that $\alpha_{0}$ is zero and $\alpha_{1}$ close to

$\delta_{0}+\gamma_{0}=\alpha_{0} ; \delta_{1}+\gamma_{1}=\alpha_{1}$ (constant)

$\phi_{\mathrm{t}} ; \mathrm{v}_{\mathrm{t}} ; \xi_{\mathrm{t}}$ error terms

The test of trade-off theory in this study conducted by the method of partial adjustment process (used also by Fama and French, 2002; Flannery and Rangan, 2006) as follows:

$$
D_{t t}=8 D_{t i}+(1-8) D_{t t-1}+e_{i t}
$$

where:

$D_{t t}=$ actual debt ratio

$\delta^{0} D_{t:}{ }^{*}=$ target debt ratio

$e_{u t} \quad=$ error term which $e_{u t} \sim \operatorname{IDD}\left(0, \sigma \mathrm{e}^{\wedge} 2\right)$

$\delta \quad=$ the speed of adjustment

Econometric specification of the target debt ratio is:

$$
D_{t i}^{*}=\sum_{k=1}^{n} \beta_{k} x_{k t t}+u_{t}+\lambda_{t}+\epsilon_{t t}
$$

where :

$\beta_{k} \quad=$ coefficient

$\mathrm{X}_{\mathrm{kit}}=\mathrm{k}$-th factor for the company i know $\mathrm{t}$

$u_{i} \quad=$ the specific influence of the companies that do not depend on time

$\lambda \_$_ $=$the specific influence of the time that is independent of the company

If equation (5) is substituted into equation (4), it will obtain:

$$
\begin{gathered}
D_{t}=\delta\left(\sum_{k=1}^{n} \beta_{k} x_{k t}+u_{t}+\lambda_{t}+\theta_{t}\right)+(1-\delta) D_{t-1}+\theta_{t} \\
D_{t t}=(1-\delta) D_{t-1}+\sum_{k=1}^{n} \beta_{k} x_{k t}+u_{t}+\lambda_{t}+\theta_{t t}
\end{gathered}
$$

where:

$u_{i} \quad=$ constant equation of time series

$\lambda_{t}=$ constant cross section equation

Furthermore, to simplify the above equation, then we let $\varphi_{0}=(1-\delta) ; \varphi_{k}=\delta \beta_{k} ; v_{i}=\delta u_{i}$; $\vartheta \hat{t}_{t}=\delta \lambda_{t}$; and $\varepsilon_{i t}=\delta e_{i t}$, the equation becomes:

$$
D_{t z}=\varphi_{0} D_{t t-1}+\sum_{k=1}^{m} \varphi_{k} x_{k t t}+v_{t}+\vartheta_{t}+g_{t t}
$$

According to Dang (2006), the determinant factor of the target debt ratio, are as follows: (1) collateral value of assets (CVAS), ratio between tangible fixed assets ratio and the total assets, both are the book values; (2) non-debt tax shield (NDTS), measured by the depreciation divided by total assets; (3) profitability (PRFT), measured bu profit to total assets ratio or total equity. This study used return on assets; (4) growth (GRTH), measured by the change of total assets or total sales. This study 
used the change in total assets is to calculate the average growth rate of assets; (5) size (SIZE), measured by Ln of total assets or Ln of total sales. This study used the Ln of Total Assets.

\section{RESULTS AND DISCUSSION}

This section describes the research finding, consists of descriptive, pecking order theory testing and trade-off theory testing.

\section{Descriptive Statistics}

Descriptive statistics of variables are as in Table 2 and Table 3 with minimun and maximum value, mean and standard deviation.

Table 2 Descriptive Statistics of Pecking Order Theory Testing

\begin{tabular}{lrrrr}
\multicolumn{1}{c}{ Variable } & \multicolumn{1}{c}{ Minimal } & \multicolumn{1}{c}{ Maximal } & \multicolumn{1}{c}{ Mean } & \multicolumn{1}{c}{ Std.Deviation } \\
\hline CF (cash flow) & $-7,155,464$ & $4,367,252$ & -41089.533981 & 1558730.3515502 \\
DIV (dividend) & 0.0000 & 11.381 & 2296.155340 & 1949.4504543 \\
C (net cash flow) & $-1.3044 \mathrm{E} 11$ & $4.4724 \mathrm{E} 12$ & $7.165906 \mathrm{E} 10$ & $4.7581338 \mathrm{E} 11$ \\
E (equity) & $-5.7583 \mathrm{E} 10$ & $3.3792 \mathrm{E} 12$ & $1.120433 \mathrm{E} 11$ & $4.3085753 \mathrm{E} 11$ \\
D (debt) & $-8.12864 \mathrm{E} 11$ & $1.0939 \mathrm{E} 12$ & $5.968288 \mathrm{E} 10$ & $2.2235432 \mathrm{E} 11$ \\
DL (long term debt) & 1,848 & $9.6014 \mathrm{E} 11$ & $3.602083 \mathrm{E} 10$ & $1.3464464 \mathrm{E} 11$ \\
DS (short term debt) & 8,740 & $9.7890 \mathrm{E} 11$ & $9.196623 \mathrm{E} 10$ & $2.1238639 \mathrm{E} 11$ \\
DEF (deficit cash flow) & $-6.9873 \mathrm{E} 11$ & $4.1678 \mathrm{E} 12$ & $1.717262 \mathrm{E} 11$ & $5.8200594 \mathrm{E} 11$ \\
\hline
\end{tabular}

Table 3 Descriptive Statistics of Trade-Off Theory Testing

\begin{tabular}{lrrrr}
\hline \multicolumn{1}{c}{ Variable } & \multicolumn{1}{c}{ Minimal } & \multicolumn{1}{c}{ Maximal } & \multicolumn{1}{c}{ Mean } & \multicolumn{1}{c}{ Std.Deviation } \\
\hline DEBT (debt) & 34,612 & $1.2557 \mathrm{E} 13$ & $3.250385 \mathrm{E} 11$ & $1.4180761 \mathrm{E} 12$ \\
EQUITY (equity) & 31,965 & $1.2800 \mathrm{E} 13$ & $5.479079 \mathrm{E} 11$ & $1.6037184 \mathrm{E} 12$ \\
FA (fixed assets) & 81,634 & $1.7056 \mathrm{E} 13$ & $4.255828 \mathrm{E} 11$ & $1.9168259 \mathrm{E} 12$ \\
TA (total asset) & 791,575 & $3.0379 \mathrm{E} 13$ & $1.283002 \mathrm{E} 12$ & $3.7942159 \mathrm{E} 12$ \\
DEP (depresiation) & 6,756 & $7.1077 \mathrm{E} 12$ & $2.172806 \mathrm{E} 11$ & $9.4982971 \mathrm{E} 11$ \\
LB (earning afrer tax) & 11,009 & $6.2342 \mathrm{E} 12$ & $1.379530 \mathrm{E} 11$ & $6.8487728 \mathrm{E} 11$ \\
D_DR (debt ratio) & -0.1306 & 0.0610 & -0.009198 & 0.0214504 \\
CVAS (Collateral Value of Assets) & 0.0078 & 3.6151 & 0.304370 & 0.4137063 \\
NDTS (Non-debt Tax Shield) & 0.0001 & 0.8964 & 0.175719 & 0.1859034 \\
PRFT (Profitability & -0.1003 & 0.3677 & 0.078164 & 0.0728428 \\
GRTH Growth) & -60.8576 & 0.9610 & 0.082448 & 0.6733810 \\
SIZE (Size) & 5.8985 & 13.4826 & 10.061658 & 2.0743027 \\
DD_DR (Debt Ratio(t-2)) & 0.0000 & 0.1306 & 0.017116 & 0.0215290 \\
\hline
\end{tabular}

\section{Pecking Order Theory Testing}

Table 4 presents the results of pecking order testing as in model (2), (3) and (4). The regression results show that all of the three models are statistically significant at the $1 \%$ level with $\mathrm{F}$ value of $159.536 ; 17.119$; and 32.539 respectively for model (2), (3) and (4). R square and adjusted R square are high only in model (2). 
As described in model testing, the simplest form of the pecking order model is the prediction that $\alpha 0$ is zero and $\alpha 1$ close to 1 . The constant values of model (2), (3) and (4) are 8.344E9, $2.090 \mathrm{E} 10$ and $6.103 \mathrm{E} 10$ repectively but the $\mathrm{t}$ values statistically significant at the $1 \%$ level only in model (4). These suggest that $\alpha 0$ for model (2) and (3) are zero, while model (4) is not zero. The $t$ values of coefficient Fin ( $\alpha 1)$ of model (2), (3) and (4) are all statistically significant at the 1\% level and the coefficients are $0.299,0.088$ and 0.180 respectively. Those coefficients do not close to 1 . Because of all models haven't $\alpha 0$ zero and $\alpha 1$ doesn't close to 1 then the pecking order is not supported. The results are consistent for model (2), (3) and (4). The result of this study is supported Fama and French (2002), Frank and Goyal (2003) and Flannery and Rangan (2006) that are not supported the pecking order model.

Table 4 Pecking Order Theory Testing

\begin{tabular}{|c|c|c|c|}
\hline & $\begin{array}{l}\text { Model (2) } \\
\text { D (delta total debt) }\end{array}$ & $\begin{array}{l}\text { Model (3) } \\
\text { DL (delta long term debt) }\end{array}$ & $\begin{array}{l}\text { Model (4) } \\
\text { DS (delta short term debt) }\end{array}$ \\
\hline Constant & 8.344E9 & $2.090 \mathrm{E} 10$ & 6.103E10 \\
\hline t value $\left(\alpha_{b}\right)$ & 0.584 & 1.625 & $3.199 * * *$ \\
\hline Fin $\left(\alpha_{1}\right)$ DEF & 0.299 & 0.088 & 0.180 \\
\hline t value & $12.631 * * *$ & $4.137 * * *$ & $5.704 * * *$ \\
\hline F value & $159.536^{* * *}$ & $17.119 * * *$ & $32.539 * * *$ \\
\hline Sig. & 0.000 & 0.000 & 0.000 \\
\hline $\mathbb{R}^{2}$ & 0.612 & 0.145 & 0.244 \\
\hline Adjusted $\mathrm{R}^{2}$ & 0.608 & 0.136 & 0.236 \\
\hline $\mathrm{N}$ & 103 & 103 & 103 \\
\hline
\end{tabular}

The second, third and forth colomns are regression results of model (2), (3) and (4) respectively. *** significant at $\alpha 1 \%$

\section{Trade-off Theory Testing}

Table 5 presents the results of Trade-Off Theory testing. The regression results show the model is statistically significant at the $1 \%$ level with $\mathrm{F}$ value of 247.133 and $\mathrm{R}$ square 0.755 .

Table 5 Pecking Order Theory Testing

\begin{tabular}{cccc}
\hline & Coefficients & t value & Sig. \\
\hline Constant & 0.001 & 0.215 & 0.830 \\
DD_DR & 0.015 & 0.567 & 0.572 \\
CVAS & 1.586 & $25.970^{* * *}$ & 0.000 \\
NDTS & 0.024 & 0.894 & 0.373 \\
PRFT & 0.064 & $2.436^{* *}$ & 0.017 \\
GRTH & 0.753 & $1.383^{* * *}$ & 0.000 \\
SIZE & 0.014 & -0.514 & 0.608 \\
F Value & $247.133^{* * *}$ & & \\
R Square & 0.755 & & \\
Adjusted R Square & 0.753 & & \\
\hline \multicolumn{4}{c}{$* * *$ significant at $\alpha 1 \%$; $*$ significant at $\alpha 5 \%$}
\end{tabular}

Unfortunately, independent variables are not all statistically significant, described as follows. The coefficient of speed adjustment is +0.015 but not statistically significant. This suggests that the speed adjustment doesn't influence Debt Ratio. Coefficinet of Collateral Value of Assets +1.586 and statistically significant at $\alpha 1 \%$. This suggets that the higher the Collateral Value of Assets, the higher 
the Debt Ratio. The coefficient of Non-debt Tax Shield is +0.024 but not statistically significant. The coefficient of Profitability is +0.064 and statistically significant at $\alpha 5 \%$. This suggests that the higher the Profitability the higher the Debt Ratio. The coefficient of Growth +0.753 and statistically significant at $\alpha 1 \%$. This suggets that the higher the growth the higher the Debt Ratio. The coefficient of Size is +0.014 but not statistically significant.

Trade-Off Theory in this study as in Fama and French (2002) is suported if $\alpha=0$ and coefficient $\delta \geq 1$. The regression result show that $r_{0}$ is 0.015 . From the equation in research method, $\varphi_{0}=(1-\delta)$, where $\delta$ shows the speed adjustment of debt ratio target debt ratio. Since $\delta=100 \%$ $1,5 \%$ or the speed adjustment is $98.5 \%$ within 2 years, then Trade-Off Theory as in Fama and French (2002) is supported. This result also consistent with Dang (2006) in English and Darminto (2011) in Indonesia.

\section{CONCLUSION}

This study presents an analysis of the pecking order theory (POT) and trade-off theory (TOT) of capital structure. POT explains that the order of financial sources used by the company was the source of internal funds from profits, short-term securities, debt, preferred stock and common stock last. POT predicts that the issuance of equity (common stock) is the last alternative sources of funding, while TOT predicts optimal capital structure. Samples in this study are companies listed in the IDX during 20092010. The research questions are tested by running regression models as in Shyam-Sunder and Myers (1999) and Cotei and Farhat (2008) and Fama and French (2002).

The result of the first test (POT) shows that $\alpha_{0}$ is not zero and $\alpha_{1}$ doesn'tclose to 1 . This suggests that POT is not supported. The results are consistent for model (2), (3) and (4). The result of the second test shows that even $\alpha_{0}$ is zero but $\alpha_{1}$ doesn't close to 1 . This suggests that the POT is not supported. The result of this study is supported by Fama and French (2002), Frank and Goyal (2003) and Flannery and Rangan (2006) that do not support the pecking order model. The result of the second test (TOT) shows that $\delta$ as the speed adjustment of debt ratio target debt ratio is $98.5 \%$ within two years, then Trade-Off Theory as in Fama and French (2002) is supported. This result is also consistent with Dang (2006) in English and Darminto (2011) in Indonesia. This suggests that the capital strucure of listed companies in Indonesian Stock Exchange is financed based on optimal capital structure, not by the order financial resources.

\section{REFERENCES}

Cotei, Carmen \& Farhat Joseph. (2008). Testing capital structure theories: are the models's assumptions correctly specified? European Journal of Economics, Finance and Administrative Sciences, 11.

Dang, V. A. (2006). Testing the Trade-off and Pecking Order Theories: A Dynamic Panel Framework, Unpublised Paper. University of Leeds, U.K.

Darminto. (2010). Pengujian teori trade-off dan teori pecking order dengan satu model dinamis pada perusahaan publik di Indonesia. Seminar on Corporate Finance, 1-11.

Fama, E. F. \& French, K. R. (2002). Testing tradeoff and pecking order predictions about dividends and debt. Review of Financial Studies, 15, 1-33. 
Flannery, M. J. \& Rangan, K. P. (2006). Partial adjustment toward target capital structures. Journal of Financial Economics, 79, 469-506.

Frank, M. Z. \& Goyal, V. K. (2003). Testing the pecking order theory of capital structure. Journal of Financial Economics, 67, 217-248.

Gunarsih, Tri. (2003). The Impact Of Governing Mechanism (Ownership Structure) and Diversification on the Performance of the Firms in Jakarta Stock Exchange. Unpublished dissertation. Gadjah Mada University, Yogyakarta.

Jensen, Michael C. \& Meckling, William H. (1976). Theory of the firm: managerial behavior, agency cost and ownership structure. Journal of Financial Economics, 3, 305-360.

Lucas, D. \& McDonald, R.L. (1990). Equity issues and stock price dynamics. Journal of Finance, 45, 1019-1043.

Myers, Stewart C. \& Majluf, Nicholas S. (1984). Corporate Financing and investment decisions when firms have information that investors do not have. Journal of Financial Economics, 13, 187221.

Myers, Stewart C. (1984). The capital structure puzzle. Journal of Finance, 39, 575-592.

Shyam-Sunder, L. \& Myers, S. (1999). Testing static tradeoff against pecking order models of capital structure. Journal of Financial Economics, 51, 219-244.

Tsuji, Chikashi. (2011). An international survey of the evidence on the pecking order theory of corporate financing. Business and Economics Research, 1(1). 